\title{
Irish and Translation - the EU Context
}

\section{Seán Ó Riain}

\section{(2) OpenEdition}

\section{Journals}

\section{Electronic version}

URL: http://journals.openedition.org/etudesirlandaises/1958

DOI: 10.4000/etudesirlandaises. 1958

ISSN: 2259-8863

\section{Publisher}

Presses universitaires de Rennes

\section{Printed version}

Date of publication: 30 December 2010

Number of pages: $65-80$

ISBN: 978-2-7535-1246-7

ISSN: 0183-973X

\section{Electronic reference}

Seán Ó Riain, «Irish and Translation - the EU Context », Études irlandaises [Online], 35-2 | 2010, Online since 30 December 2012, connection on 01 May 2019. URL : http://journals.openedition.org/ etudesirlandaises/1958; DOI : 10.4000/etudesirlandaises.1958

This text was automatically generated on 1 May 2019.

(C) Presses universitaires de Rennes 


\title{
Irish and Translation - the EU Context
}

\author{
Seán Ó Riain
}

\section{EDITOR'S NOTE}

All views expressed in this paper are personal to the author.

\section{Introduction}

1 The present survey aims to examine briefly the situation of Irish following recent statusrelated developments, particularly at EU level. To place the EU decision in context, we will evaluate recent developments, consider the complex historical and political background to Ireland's relationship to its language which influence these developments, and go on to look at current language usage. A recent publication points out the wider implications of the problems and opportunities faced by the Irish language. "As English increasingly encroaches...in higher education right across Europe... many other languages in the EU will soon face to varying degrees the challenges currently confronting Irish ${ }^{1}$ ". Suzanne Romaine thinks that "Irish warrants our gaze for what it may tell us of the fate that globalization portends for the survival of the world's linguistic diversity". For historical reasons ${ }^{3}$ there is a substantial academic literature relating to language planning in Ireland, and some of the more important material is included in the bibliography below ${ }^{4}$.

\section{The European Dimension}

2 In October 1972, I was travelling by bus from Limerick to Galway to begin my studies at NUIG (National University of Ireland, Galway). Behind me sat two other first-year students, one of whom was intent on studying Irish at university. His colleague convinced him not to do so. His decisive argument: "Europe has not made Irish official, therefore it 
has no future!" It would be difficult to find a clearer example of the effect of macro-level decisions in Brussels on the micro-level of students' choice of university subjects. Happily, this negative impact of an EU decision on the Irish language has now changed to positive.

On 13 June 2005 the $\mathrm{EU}^{5}$ Council of Ministers decided unanimously that the Irish language should become the EU's $21^{\text {st }}$ official and working language (there are now 23). The decision took effect on 1 January 2007. This was the first time that the EU decided to change its official and working languages regime, apart from adding the official languages of new member states at each enlargement. What led to this unique decision, and what were its consequences? Why are the Irish people so attached to a language that most of them do not speak regularly? Why did Ireland not seek normal status for Irish when it joined the EU in 1973?

The EU decision on Irish has already had knock-on effects, both in Ireland and on neighbouring Celtic languages. Domestically, there has been a substantial increase in those studying Irish at university level, e.g. from 2007 to 2009, the number doubled at Maynooth University, and increased from 280 to 380 at NUIG ${ }^{6}$. The effect on our neighbours has been no less marked: on 15 July $2008^{7}$, the Council of Ministers granted the status of "co-official language" to Welsh, Scottish Gaelic and any other language recognised by UK legislation. UK Ministers have since spoken both Welsh and Scottish Gaelic at Council meetings, and citizens are able to write to EU institutions and receive a reply in those languages ${ }^{8}$. Welsh and Scottish Gaelic thus joined Catalan, Basque and Galician, on which co-official status was conferred on 13 June 2005.

\section{What led to full EU status for Irish?}

5 When Ireland joined on 1 January 1973, Irish acquired a unique status as a "treaty language", though not an official and working language, of the EU. This meant that the Irish version of primary legislation, such as the Treaty of Rome and subsequent treaties, and the versions in the official and working languages would, from a legal viewpoint, be equally authentic. During accession negotiations Ireland had sought a status of "official but not working" language for Irish, but this was not agreed, as a number of member states feared that such a decision could have implications for the status of their own languages. However, Ireland's first representative in the European Court of Justice, Cearbhall ó Dálaigh, later President of Ireland, did secure official and working language status for Irish, but only at the Court.

6 A decision to add Irish would have been in line with the handling of the official languages of all other member states, both before and since' ${ }^{9}$. The official reason given by Ireland's negotiators in 1972 was that its use as a full EU working language would give rise to "certain practical difficulties". Denmark joined the EU at the same time as Ireland, and it is said that the Danish negotiating team was asked informally if it could follow Ireland's example by not requesting full working language status for Danish. The Danes replied 
that they could consider this only if the representatives of all other member states agreed to use a second language at EU meetings. The idea was dropped.

In subsequent years it became increasingly clear in Ireland that the 1972 decision was not satisfactory. It had not taken account of a number of factors:

- First, for employment in many EU institutions there has traditionally been a requirement of a knowledge of two other EU languages by applicants, in addition to the mother tongue. The 1972 decision meant that Irish would not count towards this employment condition, despite the Irish state's own requirement that all children study Irish in all state-funded schools at primary and post-primary level. This contradiction increased Irish unease.

- Second, the perception that Irish did not have a role in "Europe" was militating against the language's status within Ireland. Some peripheral groups were quoting this in support of their efforts to weaken the position of Irish within the educational system. This added to the unease of a large body of opinion, and ran counter to the general strengthening of the language in Ireland north and south over the past 30 years. The latter included an Irishlanguage TV service, TG4, since 1996; publishing continuing to thrive, the phenomenal growth of Gaelscoileanna, the Irish-medium schools, since 1972; culminating in the enactment of the Official Languages Act, 2003.

- Third, the EU enlargement of 2004, with the advent of 10 new member states and nine new official and working languages, was widely perceived in Ireland as an opportunity to review the 1972 decision regarding Irish. The addition of the new languages, some of whose states were much smaller than Ireland and whose literary traditions far shorter than Irish, contributed to making the language question a political issue.

8 This situation fed into a tradition of popular support for Irish and of protest about language matters in Ireland which goes back at least a century. Conradh na Gaeilge, the main Irish language organisation, led and won two major campaigns in the early $20^{\text {th }}$ century to have Irish taught as a core subject in schools, and to have it made an essential subject for entry to the new National University of Ireland ${ }^{10}$. The latter campaign brought over 100,000 onto the streets of Dublin, and made Irish essential for university entry in 1913, some nine years before Irish independence.

\section{EU Enlargement 2004}

9 The period leading up to the $2004 \mathrm{EU}$ enlargement saw a renaissance of this tradition of street protest, following a very effective lobbying campaign by an organisation called Stádas (status), which harnessed support from all political parties and local authorities throughout Ireland. In April 2004 thousands were back on the streets of Dublin bearing placards in all of the then $20 \mathrm{EU}$ official languages calling for "Official Status for Irish Now". The campaign make wide use of the Internet: a petition containing over 80,000 signatures was presented to the government following the march.

On 14 July 2004 the government decided to seek EU official and working language status for Irish. The EU language regime, fixed by Council Regulation 1 of 15 April 1958, is one of the few areas where the right of initiative does not belong to the Commission, but to the Council. The Irish wish for change could build on the EU status which Irish had been given from the beginning. This already had certain practical effects, such as the appearance of Irish on the EU common passport. The unusual, but very real, status of Irish within the EU had been further strengthened by the Treaty of Amsterdam in 1997, 
which formally gave the right to Irish speakers to write to the EU institutions, and to receive a reply, in Irish.

11 Among the relevant external political factors were the positions of Spain and France. Spain wished to upgrade the EU status of its regional languages, Catalan, Basque/Euskera, and Galician. Ireland supported this upgrade, but was careful to keep the two issues separate, as one related to the national language of a Member State, whereas the other related to regional languages within a Member State. France feared that full status for Irish could lead to requests for similar status for all languages used in Member States, but was reassured that a precedent would not be created by the Irish proposal. At an early stage, the United Kingdom gave an undertaking not to oppose the Irish request and Germany offered its support in July 2004. Luxembourg was helpful to Ireland in not pushing for any status change for Lëtzebuergesch. The other EU member states assured Ireland, bilaterally, of their agreement.

\section{Consequences of the new EU Status of Irish for translation/interpretation}

12 An early Irish decision was to take a pragmatic approach, by derogating from the complete application of translation and interpretation into and from Irish of all documents, and at all meetings, to a more realistic initial stage of concentrating on regulations for co-decision of the Council and the European Parliament. This derogation is reviewed at five-yearly intervals, beginning during 2010, in line with the practical functioning of the new regime for Irish. The draft Irish Government 20-year Strategy for Irish ${ }^{11}$ commits the government to "work... so that this derogation can be ended during the lifetime of this Strategy", i.e. the period 2010-30. The regime in force for Maltese provided a useful guide here, although the Maltese derogation was lifted in 2007, after three years of EU membership. Costs were kept as low as possible, and the eventual agreement foresaw the recruitment of some 30 translators and interpreters, at a cost of some $€ 3.5$ million per year, which amounts to less than one euro cent per EU citizen per year. On 1 January 2007 the nameplates which designate the country at all EU meetings changed from "IRELAND" to "ÉIRE-IRELAND" - the country's name in its national language comes first.

13 The European Commission and the Council have interpreted the new situation generously, by, for instance, setting up separate Irish language translation units, and the Commission has ensured that an increasing portion of the EUROPA website appears in Irish $^{12}$. The present author was seconded to Commission in September 2007, with a brief to produce translations for the Commission's website, and "to contribute to the evolution of language policy". Some 4,000 website pages now appear in Irish, but this is dwarfed by the total number of pages of the EUROPA website, which come to some 6 million. This experience has given some insights into translation into Irish which may be of interest.

The influence of English syntax on translators into Irish, particularly those who do not have fluency in other languages, is real, and can sometimes lead to needless disagreement. Given the ubiquitous influence of English in present-day Ireland, it can also apply to native speakers of Irish. A useful antidote is wide reading in the older classical Irish literature, such as Seathrún Céitinn or Aogán ó Rathaile, or the literary translations of authors such as Seosamh Mac Grianna. Some specific examples: 
15 a) "European Central Bank System" was translated as "An Córas Eorpach Banc Ceannais", using a genitive plural of the word "banc" by more traditional translators; and as "An Córas Eorpach Bainc Cheannais" by their more progressive colleagues, leading to long disagreement. A knowledge of the German formulation, "Europäisches System der Zentralbanken"would have led to the more traditionally Irish, and uncontroversial, "Córas Eorpach na mBanc Ceannais", with the article placed as in German.

b) "The Former Yugoslav Republic of Macedonia" had been mistranslated in Dublin as "Iar-Phoblacht Iúgslavach na Macadóine", which means "The Yugoslav Former Republic of Macedonia". This may have been partly due to French ("Ancienne République yugoslave de Macédoine") as well as to English influence: it had escaped notice that the Irish hyphenated word "Iar-Phoblacht" is an inseparable unit, meaning "Former Republic", unlike the two separate French words "Ancienne République". The formulation has now been corrected to "Poblacht Iar-Iúgslavach na Macadóine".

- Legal translation needs to be very precise, so that terms which had fallen together or were used in different parts of Ireland, such as the southern "tuairim" and the northern "barúil", both used to mean "opinion", are technically differentiated in EU texts, with "tuairim" used for "opinion" and "barúil" for "observation".

- Sometimes the problem is a plethora of Irish words in use for one English term, for instance, the word "dialogue" has been translated variously as "comhphle", "idirphle", "agallamh" or " comhagallamh". "Website" appears as both "suíomh gréasáin" and "láithreán gréasáin", though the former is now more common.

- The term "cónaidhm" had been in use for both "federation" and "confederation", and clearly needed to be differentiated. It is now used for "confederation", and "feidearálacht" is used for "federation".

- English influence on Irish has been found even in Irish language textbooks, so that one sometimes finds an Irish word carrying an English meaning, as Hiberno-English often attributed Irish meaning to an English word. The Irish word, "clann", meaning "children" can be found as a translation of the English word "family", properly "teaghlach" or "lion t $t$ ". The Hiberno-English usage of "family" to mean "children" appears to be fading.

17 In general, the substantially increased use of Irish since the passing of the Official Languages Act in 2003, and the work of eminent translators such as Breandán ó Doibhlin and others, is causing Irish to regain the precision it had when in wide use as a literary language throughout Ireland and most of Scotland from the $12^{\text {th }}$ to the $17^{\text {th }}$ centuries. The national terminology database for Irish, [www.focal.ie], was developed by Fiontar, DCU in collaboration with An Coiste Téarmaíochta and Foras na Gaeilge. It now contains over 300,000 terms, is constantly revised and updated in response to needs, and is playing a key role in modernising and streamlining Irish language terminology. A comprehensive revision of written standard Irish, the "Caighdeán Oifigiúil", is also underway, and is to be completed by June $2011^{13}$.

One of the spin-off effects of EU status has been a marked increase in Irish language activity in the vicinity of EU institutions, such as Brussels or Luxembourg. In Brussels, an Irish language week, or Seachtain na Gaeilge, has been organised during the St. Patrick's Day period each year since 2008. It comprises lectures, concerts, films, a children's' event, an Irish-language mass. A new Irish language journal, Anam Beo $\mathrm{B}^{14}$, began to appear in June 2008. Its launch received a surprising amount of media attention in Ireland ${ }^{15}$. It continues an important tradition of publishing in Irish at the Irish College in Leuven since it was 
established in 1607 (ó Cléirigh 1985). Anam Beo can be read online on the website of the Commission's representation in Dublin ${ }^{16}$.

\section{The wider context - historical background}

Irish and its offshoots, Scottish Gaelic and Manx, constitute the Gaelic branch of the Celtic languages. Welsh, Cornish and Breton and the now extinct Gaulish form the Brittonic or P-Celtic ${ }^{17}$ group, and all Celtic languages form part of the Indo-European family of languages. Referring to Irish as "Gaelic", "gaélique", "Gälisch",etc. is perceived by many Irish-speakers as an implicit denial of the language's constitutional status, as the "national and first official language of Ireland" (Article 8). It also leads to confusion with " Scottish Gaelic", sometimes called simply "Gaelic". The abbreviation GA, based on the Irish word for Irish, Gaeilge, may add to the confusion. All EU institutions have now accepted the term "Irish, irlandais, Irisch, irlandés, irlandese, irlandzki jĘzyk", but one still sometimes hears colleagues saying "gaélique" and being corrected. Irish is the language from which most Irish place names and surnames derive.

There was cultural unity between Ireland and Gaelic Scotland for many centuries. Both were to bear the brunt of an expansionist English monarchy. The first laws against Irish, the Statutes of Kilkenny, were enacted in $1366^{18}$. While Queen Elizabeth I of England studied Irish ${ }^{19}$ and financed the translation of the bible into Irish, her successor, James I took a very different attitude :

Forasmekle as the kingis Majestie having a speciall care and regaird that... the vulgar Inglish toung be universalie plantit, and the Irishe language, which is one of the cheif and principall causis of the continewance of barbaritie and incivilitie... may be aboleit and removit ${ }^{20} \ldots$

Despite such efforts, Irish arguably remained the language of the majority in Ireland until the mid-1 $19^{\text {th }}$ Century, when a number of factors caused a very rapid decline. Chief among them was the Great Famine of $1845-47^{21}$, in which 1-2 million, almost all of them Irish speakers, died of hunger. The flight from the language then accelerated. De Fréine says that it declined about 16 times as rapidly as Scottish Gaelic, leading to the situation recorded by the 1891 census, that a mere $3.5 \%$ of pre-school children spoke Irish ${ }^{22}$. Such a language shift, as de Fréine points out, is "unique in European history". To make it possible, the traditional Irish esteem for their language, as attested in its literature, and the memory of what it once had been, had to be expunged from the national consciousness.

The Irish language had produced the oldest written literature north of the Alps ${ }^{23}$, and has an unbroken literary tradition of over 14 centuries: the oldest literary text, the Amra Choluim Cille (Lament for St. Colm Cille), was written in 597 A.D. Old Irish literature was extensive, and its high quality has been recognised by non-Irish scholars. The 12-volume Patrimoine littéraire européen edited by Prof. Jean-Claude Polet, an anthology of European literature from the Atlantic to the Urals and from the beginning of written literature to the 20th Century, devotes $4.89 \%$ of its content to literature translated from Irish ${ }^{24}$. Indeed, Quirk et al. attribute to "the influence of Irish" the fact that Old English evolved a vernacular literature some centuries earlier than the other Germanic languages ${ }^{25}$. 


\section{The use of Irish today}

Comparisons of Irish with other languages based on numbers of native speakers tend to be misleading. Unlike most languages, the amount of Irish in use has little relation to numbers of native speakers, for which, in any case, there is no official figure. Up to onethird of current home users of Irish had no conversational use of the language, when children, at home or in school ${ }^{26}$. On the other hand, native speakers of Irish may live in circumstances which give little scope for active use of the language - though the substantial expansion of Irish in the electronic media over the past decade does provide ample opportunity for passive use.

The 2006 Census $^{27}$ showed 1.66 million people (up from 1.54 million in 2002), or $42 \%$, claiming a knowledge of Irish, but only 72,000 , less than $2 \%$, speaking it daily outside school. Some 97,000 speak it at least weekly, and it is significant that only $25 \%$ of the $1.66 \mathrm{~m}$ Irish speakers never actually speak $\mathrm{it}^{28}$. According to the 2001 UK Census, 167,000 , or $10.4 \%$, of the population in Northern Ireland reported some knowledge of Irish, up from 142,000 in 1991. The total claiming a knowledge of Irish is therefore over 1.8 million, or about one-third of those living on the island of Ireland.

Over 85 years of teaching Irish in all state-funded schools has vastly increased ability to speak the language, but has neither had an appreciable effect on frequency of active usage, nor has it helped establish new Irish-speaking communities. The crux of the problem is a failure to appreciate that language usage needs to be planned ${ }^{29}$, as it is a social and not an individual phenomenon. Admittedly, passive usage has increased - some $86 \%$ have tuned in to the Irish language TV channel TG4 at some point, and 800,000 do so daily ${ }^{30}$. ó Giollagáin et al.'s core point is stark:

The unambiguous conclusion of the survey on young people is that Irish is unlikely to remain the predominant community language in category A Gaeltacht districts for more than another fifteen to twenty years ${ }^{31}$.

A significant development, both in regard to translation and to general use of Irish, was the passing of the Official Languages Act, $2003^{32}$. The law was enacted to promote the use of Irish through the use of phased language schemes, which public bodies must agree with the minister, to increase incrementally their level of services to the public in both official languages. It also provides for the simultaneous publication of important official documents in both languages, thus vastly increasing translation activity. The language received a considerable political boost with the election of Brian Cowen as Taoiseach (Prime Minister) in May 2008, as he placed Irish among his three main political priorities, conducting some $35 \%$ of his first press conference in Irish. All political party leaders are now fluent Irish speakers, and this has the potential to increase its use in the Dáil. Other legislation has begun to take account of the linguistic dimension ${ }^{33}$. For instance, the Planning and Development Act, 2000, imposed, for the first time, a duty on planning authorities to 'protect the linguistic and cultural heritage of the Gaeltacht' in future development plans. Duties to promote Irish are also imposed by the Universities Act, 1997, the Education Act, 1998, the Local Government Act, 2001 and the Broadcasting Act, 2001.

Following the Belfast Agreement of 1998, the promotion of Irish in the whole island of Ireland is the responsibility of an all-Ireland body, Foras na Gaeilge ${ }^{34}$. Education and media play a crucial role in the survival of a language. Outside the Gaeltacht, there are now 169 primary schools and 38 secondary schools on the island of Ireland (31 and 2 of which, 
respectively, are in Northern Ireland $)^{35}$, which teach through Irish. They are attended by over 37,800 pupils. Adding in Gaeltacht schools (some 14,500 pupils ${ }^{36}$ ), close to 50,000 pupils are receiving some or all of their education through Irish. Provision for adult learners has been more systematic since Maynooth University introduced an examination and certification system, the Teastas Eorpach na Gaeilge (TEG) in $2005^{37}$.

The Irish language television service TG4 [www.tg4.ie] has a share of some $3 \%$ of television viewers, and is watched by 800,000 people during peak viewing hours ${ }^{38}$. Raidió na Gaeltachta (www.rte.ie/rnag) broadcasts nationally, and both Dublin and Belfast have their own Irish language radio services. Some 130 new book titles appear annually, and Nic Eoin describes Irish as "now a sophisticated, versatile and creative medium of literary analysis" ${ }^{39}$. There are lively internet magazines [www.beo.ie, www.InsideIreland.ie, www.nuacht24.com], and two weekly newspapers.

\section{Conclusion}

Even Hindley, otherwise pessimistic, acknowledges as "a great achievement... without international parallels except for Hebrew..." the "metamorphosis of Irish from the disparaged and unwritten dialects of an impoverished and remote... peasantry into the modern literary... language of a privileged urban elite ${ }^{40}$. The new EU status of Irish coincides with increased support at the top political level in Ireland. A tentative conclusion is that this happy coincidence is enhancing the practical role of Irish. Final agreement by the EU Council of Ministers to grant full official and working status to Irish was seen as a huge victory for the language. It is hard to exaggerate the psychological impact on Irish people of hearing their representatives address the EU Council of Ministers, or a plenary session of the European Parliament, in Irish. A language outlawed as long ago as 1366 has finally come in from the cold. Perhaps it is fitting to give the final word to a Scottish poet, Hugh MacDiarmid:

For we ha'e faith in Scotland's hidden poo'ers,

The present's theirs, but a' the past and future's oors ${ }^{41}$.

\section{BIBLIOGRAPHY}

CILAR, Report of Committee on Irish Language Attitudes Research, Dublin, Government of Ireland, 1975.

CISŁo, Anna, Tożsamość Irlandczyków w prozie odrodzenia literackiego, Wrocław, Uniwersytet Wrocławskiego, 2003.

Collins, Michael, The Path to Freedom, Cork, Mercier Press, 1968.

CRONIN, Michael, Irish in the New Century/An Ghaeilge san Aois Nua, Dublin, Cois Life, 2005.

CROWLEY, Tony, The Politics of Language in Ireland 1366-1922 - a Sourcebook, London/New York, Routledge, 2000. 
DE FRÉINE, Seán, The Great Silence - the study of a relationship between language and nationality, Dublin/ Cork, Mercier, 1978.

DE FRÉINE, Seán, “Tuiscint ar an nGaeilge” (Understanding of Irish), p 317-332, Dublin, An Aimsir Óg 2, 2000.

FISHMAN, Joshua, “Irish: What more can be done?", in Reversing Language Shift, Clevedon, Multilingual Matters, 1991.

HARRIS, John, Irish in Primary Schools: Long-Term National Trends in Achievement, Dublin, Department of Education and Science, 2006.

HiNDley, Reg, The Death of the Irish Language, London/New York, Routledge, 1990.

Kelly, Adrian, Compulsory Irish, Dublin, Irish Academic Press, 2002.

MAC CÁRTHAIGH, Dáithí (ed.), I dTreo Deilbhcháipéise d'Acht Teanga Éireannach (Towards a Draft Irish Language Law), Baile Átha Cliath/Dublin, Coiscéim, 1998.

MAC CORRAIDH, Seán, Seosamh Mac Grianna - aistritheoir (translator), Baile Átha Cliath (Dublin), An Clóchomhar, 2004.

MAC DONNACHA, Joe, “An Integrated Language Planning Model”, in LPLP 24:1, p. 11-36, 2000.

MAC EOIN, Gearóid, “The Decline of the Celtic Languages”, in Maclennan 1988, p. 589-602, 1988.

MAC LOCHLAIN, Antain, In Ord is in Eagar, Baile Átha Cliath/Dublin, Cois Life, 2010.

MAC MURCHAIDH, Ciarán, “Who Needs Irish?” - Reflections on the Importance of the Irish Language Today , Baile Átha Cliath (Dublin), Veritas, 2004.

MAC PÓILIN, Aodán (ed.), The Irish Language in Northern Ireland, Belfast, ULTACH Trust, 1997.

MAC SíomóIN, Tomás, Straitéis nua don Ghaeilge (A new Strategy for Irish), Baile Átha Cliath (Dublin), An Aimsir Óg, 2006.

MAGUIRE, Gabrielle, Our Own Language - an Irish Initiative, Clevedon, Multilingual Matters, 1991.

MccLosKey, James, Voices silenced - has Irish a Future?/Guthanna in Éag - an mairfidh an Ghaeilge beo?, Baile Átha Cliath/Dublin, Cois Life, 2000.

MulHolland, Gwen, The Struggle for a Language: Gaelic in Education, Inverness, Rank \& File, 1981.

Ní GHALlachaiR, Anna, “Teaching and Learning Irish Today” in NIC PHÁIDín et al., p. 191-201, 2008.

Ní SHÉAGHDHA, Nessa, Translations and Adoptations into Irish, Dublin, Instititude for Advanced Studies, 1984.

NIC CRAITH, Máiréad, Malartú Teanga: An Ghaeilge i gCorcaigh sa Naoú hAois Déag (Language Change: Irish in Cork in the Nineteenth Century), Bremen, Verlag für ESIS, 1994.

NIC EOIN, Máirín, “Prose Writing in Irish Today” in NIC PHÁIDÍN et al., p. 131-139, 2008.

NIC PHÁIDín, Caoilfhionn and ó CEARNAIGH, Seán, (eds.), A New View of the Irish Language. Baile Átha Cliath/Dublin, Cois Life 2008.

ó CEARÚIL, Micheál, Bunreacht na hÉireann (Constitution of Ireland) - A study of the Irish text, Dublin, All-Party Parliamentary Committee on the Constitutionl, 1999.

Ó CINNÉIDE, M.S., KeANE, M., CAWLEY, M., "Industrialization and Linguistic Change among Gaelicspeaking Communities in the West of Ireland", in LPLP 9:1, p. 3-16, 1985. 
ó cIosÁin, Éamon, Buried Alive - A reply to The Death of the Irish Language, Baile Átha Cliath/ (Dublin), Dáil Uí Chadhain, 1991.

ó CIOSÁIN, Séamus, "Language Planning and Irish: 1965-74" in Language, Culture and Curriculum, 1:3, Clevedon, Multilingual Matters, 1988, p. 263-279.

ó CLÉIRIGH, Tomás, Aodh Mac Aingil agus an Scoil Nua-Ghaeilge i Lobháin (Aodh Mac Aingil and the School of Modern Irish in Leuven), Baile Átha Cliath/Dublin, An Gúm, 1985.

Ó CLÉRIGH, Gearóid, An Ghaeilge - a feidhm feasta agus i gcónaí (Irish: its present and future functions), Baile Átha Cliath/Dublin, Coiscéim, 2004.

ó conchUBHAIR, Brian (ed.), Why Irish? - Irish Language and Literature in Academia, Galway, Arlen House, 2008.

Ó CORRÁIN, Ailbhe (ed.), Breandán Ó Doibhlin: Saol agus Saothar (Life and Works), Baile Átha Cliath (Dublin), Coiscéim, 2007.

ó cuív, Brian (ed.), A View of the Irish Language, Dublin, Government of Ireland, 1969.

ó DoIBHLIN, Breandán, Aistí Critice agus Cultúir III (Critical and Cultural Essays). Baile Átha Cliath/ Dublin, Coiscéim, 2009.

Ó DÚSHLÁINE, Tadhg (ed.), Irisleabhar Mhá Nuad - Féilscribhinn an Doibhlinigh (University of Maynooth Festschrift for Professor Breandán Ó Doibhlin). Maynooth, National University of Ireland/An Sagart, 1997.

Ó GIOLlaGÁIN, C., MAC DONNACHA, S., NÍ CHUALÁIN, F., Ní SHÉAGHDHA, A., O’BRIEN, M., Comprehensive Linguistic Study of the Use of Irish in the Gaeltacht/Staidéar Cuimsitheach Teangeolaíoch ar Úsaid na Gaeilge sa Ghaeltacht, Dublin, Government of Ireland/National University of Ireland, Galway, 2007. ó HIFEARnÁIn, Tadhg, Beartas Teanga (Language Policy), Baile Átha Cliath (Dublin), An Aimsir Óg, 2006.

Ó HUALLACHÁIN, Colmán, The Irish and Irish - a sociolinguistic analysis of the relationship between a people and their language, Baile Átha Cliath/Dublin, Franciscan Friars, 1994.

Ó HUALlACHÁIN, Seán Breandán, Pobal an Stáit agus an Ghaeilge 1920-39, Baile Átha Cliath/Dublin, Coiscéim, 2010.

ó HUIGINN, Ruairí (ed.), Ceist na Teanga (The Language Question), Má Nuad, An Sagart, 2001. Ó LAIGHIN, Pádraig, Acht na Gaeilge - Acht ar Strae (The Irish Language Act gone astray), Baile Átha Cliath (Dublin), An Aimsir Óg, 2003.

Ó LAIGHIN, Pádraig, "Irish and the Legislative Perspective”, in NIC PHÁIDÍN et al., p. 249-262, 2008.

Ó LAIGHIN, Pádraig, Catullus Gaelach, Baile Átha Cliath/Dublin/Montréal, Coiscéim, 2010.

Ó LAOIRE, Muiris, Athbheochan na hEabhraise: Ceacht don Ghaeilge? (The Revival of Hebrew: a lesson for Irish?), Baile Átha Cliath/Dublin, An Clóchomhar, 1999.

Ó MÁILLE, Tomás, Stádas na Gaeilge - Dearcadh Dlithiúil/The Status of the Irish Language - A Legal Perspective, Baile Átha Cliath/Dublin, Bord na Gaeilge, 1990.

Ó MURCHÚ, Helen, More Facts about Irish, Dublin, European Bureau for Lesser-Used Languages/Irish National Committee, 2008.

Ó MURCHÚ, Máirtín, Urlabhra agus Pobal/Language and Community, Baile Átha Cliath/Dublin, Government of Ireland/Comhairle na Gaeilge, 1971. 
Ó MURCHÚ, Máirtín, The Irish Language. Baile Átha Cliath/Dublin, Government of Ireland (Department of Foreign Affairs and Bord na Gaeilge), 1985.

ó MURCHÚ, Máirtín, Ag dul ó Chion? - Cás na Gaeilge 1952-2002 (Degeneration? - The Case of Irish 1952-2002), Baile Átha Cliath/Dublin, An Aimsir Óg, 2002.

Ó NÉILL, Diarmuid (ed.), Rebuilding the Celtic Languages - Reversing Language Shift in the Celtic Countries, Talybont, Y Lolfa, 2005.

Ó RIAGÁIN, Pádraig, Language Planning in Ireland. New York, International Journal of the Sociology of Language, Mouton de Gruyter, 1988.

Ó RIAGÁIN, Pádraig, Language Policy and Social Reproduction: Ireland 1893-1993, Oxford, Clarendon Press, 1997.

Ó RIAGÁIN, Pádraig, and ó GLIASÁIN, Micheál, National Survey on Languages 1993, Dublin, ITÉ/ Linguistics Institute of Ireland, 1994.

Ó RIAIN, Seán, Pleanáil Teanga in Éirinn (Language Planning in Ireland) 1919-1985, Baile Átha Cliath/ Dublin, Carbad/Bord na Gaeilge, 1994.

Ó RIAIN, Seán, The EU and the Irish Language: Identity and Linguistic Diversity, Baile Átha Cliath/ Dublin/Corcaigh, Clódhanna Teo, 2001.

Ó RIAIN, Seán, “Sprachplanung in Irland”, in Beiträge der Gesellschaft für Interlinguistik 11, Berlin, Gesellschaft für Interlinguistik, 2002.

Ó RIAIN, Seán, “Múineadh na Gaeilge: cabhair ó Esperanto?” (The Teaching of Irish: help from Esperanto?) in FEASTA, Baile Átha Cliath/Dublin, Clódhanna Teoranta, 2009.

Ó RUAIRC, Maolmhaodhóg, Aistrigh Leat (Translate away), Baile Átha Cliath/Dublin, Cois Life, 2007. Ó SÉ, Liam, Crannóga (lake dwellings): An Epidemiological Approach to the Gaeltacht. Dublin, Johnswood Press, 2000.

ó SNODAIGH, Pádraig, Hidden Ulster: Protestants and the Irish Language, Belfast, Lagan Press, 1995. Ó SÚILLEABHÁIN, Donncha, Cath na Gaeilge sa Chóras Oideachais (The Battle for Irish in the Educational System), Baile Átha Cliath/Dublin, Conradh na Gaeilge, 1988.

Ó TORNA, Caitríona, Cruthú na Gaeltachta 1893-1922, (The Creation of the Gaeltacht), Baile Átha Cliath, Dublin, Cois Life, 2005.

Ó TUATHAigh, Gearóid, ó LAOIRE, Lillis, UA SÚILlEABHÁIN, Seán, Pobal na Gaeltachta (The Gaeltacht People), Indreabhán, Cló Iar-Chonnachta, 2000.

Ó TUATHAIL, Séamas, Gaeilge agus Bunreacht (Irish and the Constitution), Baile Átha Cliath/Dublin, Coiscéim/Institiúid na Héireann, 2002.

O'LEARY, Philip (ed.), Éire-Ireland special issue on translation, Morristown, NJ, The Irish American Cultural Institute, 2000.

POLET, Jean-Claude (ed.), Patrimoine littéraire européen. Anthologie en langue française, 12 volumes. Brussels, De Boeck-Université, 1992.

POLET, JEAN-CLAUDE, « Breandán Ó Doibhlin et le Patrimoine littéraire européen » in ó DÚSHLÁINE, 1997, p. 337-345.

QUIRK, R., ADAMS, V., DAVY, D., Old English Literature. London, Edward Arnold.

RomAINE, Suzanne, 2008. “Irish in the Global Context”, in NIC PHÁIDín et al., 1975, p. 11-25. 
TITLEY, Alan, An Réabhlóid mar Ghníomh Dínite (Revolution as a Blow for Dignity), Baile Átha Cliath/ Dublin, Coiscéim, 2008.

VOGLER, Benjamin, Irisch und Walisisch im Vergleich - Ein Beitrag zur Lage der Minderheitsprachen in der Europäischen Union, Hildesheim, Universität Hildesheim, 2004.

WALSH, John, Díchoimisiniú Teanga - Coimisiún na Gaeltachta 1926 (Language Decommissioning - the Gaeltacht Commission 1926), Baile Átha Cliath/Dublin, Cois Life, 2002.

WATSON, Iarfhlaith, Broadcasting in Irish, Dublin, Four Courts Press, 2003.

\section{NOTES}

1. Caoilfhionn Nic Pháidín and Seán,ó Cearnaigh, eds, A New View of the Irish Language, Baile Átha Cliath/Dublin, Cois Life, 2008, p. x.

2. Suzanne Romaine, "Irish in the Global Context", in C. Nic Pháidín et al., op. cit., p 13.

3. Some $69 \%$ of those active in the struggle of Irish independence came from the language movement. Michael Collins, first chairman of the Provisional Government in 1922, wrote that "Irish history will recognise the birth of the Gaelic League in 1893 as the most important event of the $19^{\text {th }}$ Century" (Collins 1968: 123).

4. With considerable indisciplinary content, the work includes language planning (M. Ó Murchú, ó hIfearnáin, Ó Riagáin, Ó Huallacháin, ó Riain 1994, Ó Riagáin et al., Mac Donnacha, Ó Ciosáin, 1988, Mac Carrick, Vogler); translation (Mac Lochlainn, Ní Shéaghdha, ó Corraidh, ó Corráin, Ó Doibhlin, Ó Laighin 2010, Ó Ruairc, O’Leary); language policy in general (CILAR, Collins, Ó hUallacháin 2010, Ó Murchú, H., Greene, ó Cuív 1969, ó Clérigh, Titley, ó hUiginn, Mac Murchaidh, Cisło, Kelly, Nic Pháidín et al., ó Néill); constitutional/legal issues (ó Máille, Mac Cárthaigh, ó Laighin, ó Tuathail); education (Harris); the Gaeltacht/Irish-speaking area (Ó Giollagáin et al., Ó Tuathaigh et al. , ó Cuív 1951, Hindley, ó Ciosáin 1991, ó Cinnéide et al., ó Sé, ó Torna, Walsh 2002, Nic Craith); culture (de Fréine, Cronin, ó Doibhlin, Mac Síomóin 2006); history (ó Cléirigh, Crowley, Ó Súilleabháin, Ó Riain 1994, Mulholland); lessons from other countries (Fishman, Ó Laoire); literary studies (de Fréine 2000, Ó Doibhlin, Ó Dúshláine, Quirk et al.); broadcasting (Watson), psychological aspects (Ó Conchubhair); and Northern Ireland (Mac Póilin, Ó Snodaigh, Maguire, Mac Póilin et al.).

5. For the sake of simplicity, the term "EU" has been used throughout this paper.

6. Personal communications to author.

7. [http://new.wales.gov.uk/news/presreleasearchive/2391611/?lang=en].

8. At the expense of the Welsh Assembly and Scottish Parliament, respectively.

9. Lëtzebuergesch, which became an official language of Luxembourg in 1984 and had previously been considered a Frankish dialect, is only a partial exception, as it did not have official status in Luxembourg when that country joined the EU.

10. See Donncha Ó Súilleabháin, Cath na Gaeilge sa Chóras Oideachais (The Battle for Irish in the Educational System), Baile Átha Cliath Dublin, Conradh na Gaeilge, 1988.

11. [http://www.pobail.ie/ie/AnGhaeilge/file,10094,ie.doc].

12. [http://ec.europa.eu/index_ga.htm].

13. [http://www.pobail.ie/en/CentralTranslationUnit/]. 
14. Anam Beo means 'living soul'. The reference is to the motto of the Irish language movement, Conradh na Gaeilge, "Tír gan Teanga, Tír gan Anam" (A country without a language is a country without a soul).

15. The launch was covered by national television, by some 20 radio interviews with national and local radio, both in Irish and in English, and by the national newspapers.

16. [http://ec.europa.eu/ireland/press_office/altanna_nuachta_as_gaeilge/index_en.htm].

17. From the respective words for 'head': Irish 'ceann' (which had an initial 'q' in Early Irish), Welsh 'pen'.

18. See text in Tony Crowley, The Politics of Language in Ireland 1366-1922 - a Sourcebook. London/New York, Routledge, 2000, p. 14-16.

19. Máirtín Ó Murchú, The Irish Language., Baile Átha Cliath (Dublin), Government of Ireland (Department of Foreign Affairs and Bord na Gaeilge), 1985, p. 60.

20. Act of the Privy Council - 1616, JVI \& I. Quoted in Gwen Mulholland, The Struggle for a Language: Gaelic in Education, Inverness, Rank \& File, 1981, p. 7.

21. In 1997, when the $150^{\text {th }}$ anniversary of the Famine was commemorated, British Prime Minister Tony Blair made a crucial contribution to the peace process in Ireland by formally apologising to the Irish people for Britain's failure to take any effective action (not even banning the export of corn) at that time.

22. Seán de Fréine, The Great Silence - the study of a relationship between language and nationality. Dublin/Cork, Mercier, 1978, p. 7.

23. Seán de Fréine, "Tuiscint ar an nGaeilge" (Understanding of Irish), Dublin, An Aimsir Óg 2, 2000, p. 318.

24. Jean-Claude Polet, «Breandán Ó Doibhlin et le Patrimoine littéraire européen » in Tadhg ó Dúshláine, ed. Irisleabhar Mhá Nuad - Féilscribhinn an Doibhlinigh (University of Maynooth Festschrift for Professor Breandán Ó Doibhlin), Maynooth, National University of Ireland/ An Sagart, 1997, p. 337.

25. R. Quirk, V. Adams, D. Davy, Old English Literature. London, Edward Arnold, 1975, p. 6.

26. CILAR 1975, p 314, a finding largely confirmed by subsequent research.

27. [ http://www.cso.ie/census/census2006results/volume_9/ volume_9_irish_language_entire_volume.pdf].

28. Helen Ó Murchú, More Facts about Irish. Dublin: European Bureau for Lesser-Used Languages/Irish National Committee, 2008, p. 72, p. 370.

29. Seán Ó Riain, 1994. Pleanáil Teanga in Éirinn (Language Planning in Ireland) 1919-1985, Baile Átha Cliath (Dublin), Carbad/Bord na Gaeilge, 1994, p. 92.

30. Helen ó Murchú, op. cit., p. 219.

31. C Ó Giollagáin., S. Mac Donnacha, F. Ní Chualáin, A. Ní Shéaghdha., M. O’Brien, Comprehensive Linguistic Study of the Use of Irish in the Gaeltacht/Staidéar Cuimsitheach Teangeolaíoch ar Úsáid na Gaeilge sa Ghaeltacht, Dublin, Government of Ireland/National University of Ireland, Galway, 2007, p. 27.

32. [http://www.oireachtas.ie/documents/bills28/acts/2003/a3203.pdf]. Its provisions came into force gradually, with all provisions in force by July 2006.

33. Pádraig Ó Laighin, "Irish and the Legislative Perspective", in C. Nic Pháidín et al, op. cit ., p 254-255.

34. [http://www.gaeilge.ie/]. 


\section{5. [http://www.gaelscoileanna.ie/about/statistics/].}

36. [ http://www.cogg.ie/downloads/Gaeltacht\%20achoimre2.pdf]. Paradoxically, not all Gaeltacht pupils study through Irish.

37. Anna Ní Ghallachair, "Teaching and Learning Irish Today", in C. Nic Pháidín et al, op. cit., $\mathrm{p} 194$.

38. [http://www.tg4.ie/corp/culr.asp].

39. Máirín Nic Eoin, "Prose Writing in Irish Today" in C. Nic Pháidín et al., op. cit., p 137.

40. Reg Hindley, The Death of the Irish Language, London/New York, Routledge, 1990, p. 42.

41. Hugh MacDiarmid, Selected Poems, London, Penguin, 1992, p. 23. It is interesting to note that this line is most frequently quoted in its English version: For we have faith in Scotland's hidden powers/The present's theirs but all the past and future's ours. In Irish this could be rendrered as: Óir creidimid i gcumhachtaí ceilte na hAlban/Leosan a bhfuil, ach is linne a mbíodh's a mbeidh.

\section{ABSTRACTS}

This survey discusses the broader context of the 2005 decision to include Irish among the EU's official and working languages, particularly its effects on translation and interpretation. Irish's new EU status coincides with increased support at the top political level in Ireland, and is enhancing the practical role of Irish. However, the continuing decrease in the use of Irish by young people in the Gaeltacht is worrying, as is the failure of the authorities over many years to appreciate that language use needs to be planned. This may now be changing: recent developments give some grounds for hope.

Cette contribution examine le contexte de la décision de 2005 d'inclure la langue irlandaise parmi les langues de travail officiel de l'UE, et s'intéresse notamment aux effets de cette décision sur la traduction et l'interprétation. L'irlandais se voit conférer un nouveau statut, alors que parallèlement il bénéficie d'un soutien accru au plus haut niveau politique en Irlande, ce qui lui permet de renforcer son rôle pratique. Néanmoins, la baisse constante de l'utilisation de la langue chez les jeunes du Gaeltacht est source d'inquiétude, comme à pu l'être l'incapacité des autorités à comprendre la nécessité de planifier l'utilisation de la langue. Les récents changements constatés à ce sujet sont toutefois encourageants.

\section{INDEX}

Mots-clés: langues en Irlande - gaélique, langues en Irlande - politiques linguistiques, Union Européenne / CEE, traduction

Keywords: languages in Ireland - gaelic, languages in Ireland - language policy, European Union / EEC, translation 
AUTHOR

SEÁN Ó RIAIN

European Commission, Brussels 